\title{
Effective Management of Corporate Social Responsibility (CSR) for Desired Outcome: The Niger Delta Issue in Nigeria
}

\author{
Rebecca Oliver Enuoh ${ }^{1} \&$ Benjamin James Inyang ${ }^{2}$ \\ ${ }^{1}$ School of Management, Bradford University, Bradford, United Kingdom \\ ${ }^{2}$ Department of Business Management, University of Calabar, Calabar, Nigeria \\ Correspondence: Benjamin James Inyang, Ph.D., Department of Business Management, University of Calabar, \\ Calabar, Nigeria. Tel: 234-80-3377-3403. E-mail: benji1955.unical@yahoo.co.uk
}

Received: March 23, 2014

doi:10.5430/ijba.v5n4p32
Accepted: June 18, 2014

Online Published: June 23, 2014

URL: http://dx.doi.org/10.5430/ijba.v5n4p32

\begin{abstract}
The paper evaluates the potential of corporate social responsibility (CRS) in addressing insurgents in the Niger Delta region of Nigeria. Effective CSR is relative and depends on the peculiarity of the area in order for corporations to achieve desired results. The paper adopts a theoretical interdisciplinary methodology based on a review of literature and deductive arguments on CSR and sustainability. The paper identifies lack of effective planning and implementation of CSR by multinational oil companies as one of the contributory factors to the crisis in the region. It also notes that the issues of oil pipeline destruction, kidnapping of oil workers and oil-related contestations, inter and intra communal conflicts, crude oil theft and general insecurity have not been successfully addressed. The paper therefore recommends that sustainable development through the provision of needed basic infrastructure, sustainable livelihood initiatives and community participation strategies be put in place as solutions to the crisis. The study contributes an innovative way of CSR implementation that is based on collaborative participation rather than company policy and need assessment of CSR projects.
\end{abstract}

Keywords: corporate social responsibility, community participation, sustainability, organizational policy, Niger Delta, Nigeria

\section{Introduction}

Corporate Social Responsibility (CSR) is an important issue which has received much attention in the managerial and organizational literature (Tuzzolino and Armandi, 1991) and is an effective structure for developing complex industrial economies (Epstein, 2007). CSR is defined as the accommodation of corporate behaviour to society's values and expectations (Griseri and Seppala, 2010). CSR has also been viewed as the obligation of firms to be responsible to the environment and to their stakeholders in a manner that goes beyond financial goals (Gössling and Vocht, 2007). CSR is also described as "good citizenship," or being a "good" company that is supportive of its shareholders as well as society (Sana-ur-Rehman and Beise-Zee, 2011). In a developing country like Nigeria, CSR by multinational oil companies (MOC) like Shell has been remarkable (Idemudia and Ite, 2006b). In the Niger Delta region (NDR), most of the services and infrastructure provided by Shell (for example provision of health care facilities, road maintenance and building of schools) were either hitherto absent, inadequate or dysfunctional in the local communities (Tuodolo, 2009).

Despite the CSR activities by MOC, oil exploitation has also brought about negative impacts on the people of the NDR. Ako (2012) classifies the negative impact of oil discovery and exploitation into economic deprivation, social exclusion and environmental injustice, which have resulted in poverty in the midst of rich natural resources. George, Kuye and Onokala (2012) are of the view that constant oil spillage in the NDR has polluted the rivers and the farmlands which have in turn resulted in very little employment for young people and consequently in youth restiveness. However, there are limited studies on the impact and effectiveness of CSR in reducing the crisis within this region. The research done on the activities of Shell and its processes of delivering its CSR programme indicates that the negative costs often outweigh the positive benefits CSR brings on local communities (Newell, 2005, Tuodolo, 2009). 
Research has also shown that the CSR undertaken by oil corporations in this region is not having the desired impact and has done little or nothing to improve the living standards of the inhabitants or reducing the crisis brought about by oil exploration (Ejumudo, Edo, Avweromre and Sagay, 2012). Tuodolo (2009) is of the opinion that most of the benefits local communities enjoy from the CSR programmes of Shell come at a great cost to them. This has therefore triggered crude oil theft, kidnapping, inter-communal conflicts, destruction of oil pipelines and general insecurity in the NDR. However, the question is how then can CSR be a useful tool in reducing or eliminating the crisis in the NDR?

This paper therefore sets out to evaluate how the multinational oil companies can use CSR initiatives to address the insurgents and crises in the Niger Delta region. The paper further investigates the strategies that need to be adopted in making the implementation of CSR initiatives effective.

The paper is divided into six sections. The introductory section is followed by the second section which reviews the literature and covers the conceptual understanding of CSR and the social, economic and environmental sustainability aspects of CSR. The third section concerns the Niger Delta crisis followed by the implementation of CSR in the Niger Delta region. The fifth section discusses community participation in CSR implementation while the last section is the conclusion.

\section{Literature Review}

\subsection{Corporate Social Responsibility (CSR) - A Conceptual Understanding}

For four decades, the concept of corporate social responsibility (CSR) has undergone several academic debates. There is no agreed definition of CSR or its related terms such as corporate citizenship or corporate responsibility due to its multi-disciplinary nature and multiple conceptualizations (Garriga and Melé, 2004). The concept has been used in a variety of ways that one wonders if it is intended to convey the same meaning. CSR has seen continuous debates about its meaning, approaches and even the terminologies used to explain why businesses should see beyond making profit. Academic debates surrounding CSR have a tradition of examining relationships between business and society (e.g. Carroll, 1999; Wood, 1991). CSR is considered as an obligation for business organizations to pursue those policies, decisions and lines of actions that are desirable in terms of the objectives and values of the society (Bowen, 1953).

Hopkins (2003) sees corporate responsibility as being concerned with treating the stakeholders of the firm ethically or in a responsible manner and to create higher standard of living, while preserving the profitability of the corporation for people within and outside the corporation. CSR is also seen as a company's status and activities with respect to its perceived societal or stakeholder obligation (Dacin and Brown, 2006). Despite attempts to define the term, Carroll (1994: 14) contends that defining CSR is "an eclectic filed with loose boundaries, multiple memberships, and differing training/perspectives; broadly rather than focused, multidisciplinary; wide breadth; brings in a wider range of literature; and interdisciplinary". Votaw (1979) in Garriga and Mele (2004:52) sum up the multitude of meanings given to the concept as follows:

Corporate social responsibility means something, but not always the same thing to everyone. To some it conveys the idea of legal responsibility or liability; to others it means socially responsible behavior in an ethical sense; to still others the meaning transmitted is that of 'responsible for' in a causal mode; many simply equate it with 'charitable contributions'; some take it to mean socially conscious; many of those who embrace it most fervently see it as a mere synonym for 'legitimacy' in the context of belonging or being proper or valid; a few see it as a sort of fiduciary duty imposing higher standards of behaviour on businessmen than on citizens at large.

Over the years, many arguments have been presented for and against the concept and its impact on business performance. Friedman (1970) advances the idea of shareholder value being in conflict with corporate social responsibility. In his view, companies who engage in CSR are misusing the resources entrusted to them. It is his view that companies should focus on economic activities and productive role in society rather than performing other roles in society. Friedman (1970) also says that the primary purpose of business in society is to generate profit and so social matters are not the concern of business people and societal problems should be resolved by the unfettered working of the free market system.

The alternative view-points have been argued by others that business and its owners should comply with societal values and take an active role in society as this is in line with the long-term interest of business. On this alternative view, companies that are responsive to the various societal groups will benefit from resulting goodwill and attract high-quality employees (Griseri and Seppala, 2010). Bowen (1953) argues that businesses were responsible for 
producing 'social good' as well as goods and services for sale, and that every business had an obligation to give back to the communities that supported it. Despite arguments for and against the concept of CSR, this article agrees with Lewis (2003) that being socially responsible also enhances corporate reputation and acceptance of the community where a company is operating because corporations that are socially responsible earn the goodwill of not just its customers but the community at large. Over time issues surrounding CSR have grown beyond its mere practice to that of sustainability therefore making sustainability a major aspect of CSR that must be considered.

\subsection{Sustainability: Social, Economic and Environmental Aspects of CSR}

The issue of sustainability is an emerging one in local and international business as regards to CSR. Amongst the terms used to discuss the economic, social and environmental contributions and consequences of business practices is CSR and sustainable development (Torugsa, O'Donohue and Hecker, 2013). The World Commission for Environment and Development (WCED, 1987) notes that the practices that assure sustainability are those that meet present needs without compromising the ability of meeting the needs of future generation. It is expected that sustainability concerns should be integrated in corporations' CSR policies and practices according to the World Business Council for Sustainable Development (WBCSD, 2004). The social, environmental and economic sphere could be likened to the same message as that of the triple bottom line (people, planet and profit) of Elkington (1998) and Tullberg (2012). The social representing the people, environment as replacing planet and the economic factor being considered as profit.

The social bottom line is concerned with the people who are directly affected by the corporation's actions. They are the beneficiaries or sufferers of corporate activities. It is expected that corporation's CSR activities should be able to meet the need of the present and future society. The society plays a major role in the success of the corporation, hence the need to create a sustainable society. The social aspect is influenced by the taxes the company pays on its profits, its level of production and the wages to its employees (Tullberg, 2012). Corporations' contribution through its CSR indicates the capacity of firms' role in improvement of the quality of human life. The World Business Council for Sustainable Development (WBCSD, 2004) has issued a new guide to encourage companies to invest in sustainable livelihood business activities that meet the needs of the poor, as well as contribute to a firm's bottom line.

Arguably, it can be said that the continued existence of corporations depends on the existence of the society, hence the need for a sustainable society. The social dimension of CSR involves having the workplace and the community as two points of focus in creating social structure and equity. This social dimension should recognize the health, safety and general well-being of workers and this will enable firms to act as good citizens in the community of their domain. A CSR that involves creating a formal social dialogue that considers and recognizes the interests of all stakeholders in decision making; in so doing, mutually acceptable outcomes can result for the firm and its stakeholders.

The environmental bottom line concerns the impact of corporations' activities on the environment. This bottom line requires a balance between cost and benefits (Tullberg, 2012). Corporations are urged to reduce their negative impact on the environment in order to guarantee continued existence. The environmental dimension of CSR focuses on innovation, eco-efficiency, pollution prevention and environmental leadership. The aim is to minimize a firm's ecological impact along the entire product life cycle. This is done in order to ensure that environmental impacts from a firm's activities are monitored and managed systematically, thereby helping build a firm's credibility with external stakeholders (Walley and Whitehead, 1994). It is argued that there are times where it is totally impossible to avoid having negative impact on the environment. In this case the focus should be to avoid excess impact or to reduce the target revenue in order to achieve a positive environmental impact by maintaining agreed environmental standards of operation and best practices (Tullberg, 2012). Protecting the environment implies protecting the business for future generation.

The economic bottom line concerns profit generation of the firm in order to fulfill its motive of being in business. This dimension is aimed at supporting economic growth and prosperity. It is the means by which firms attempt to resolve issues such as: customer satisfaction, product quality and safety and supply chain management (Torugsa et al., 2013). The economic responsibility is concerned with core business activities and decision-making processes. Firms are expected to go beyond short-term profit maximizing issues to emphasize long-term economic performance issues, and the effective exploitation of market opportunities, as well as contribute to the improvement of the standard of living across the whole economy (Wagner, 2010). Economic-related CSR creates value through fostering the development of new and different products that are desired by consumers, lowering the costs of inputs, and improving production efficiencies. Corporations can only do business by staying in business (Tullberg, 2012). This bottom line does not only consider how much profit corporations generate but how the profit is generated and 
ploughed back to the society and environment. Therefore the social and environmental concerns can hardly be accommodated in CSR engagements without corporations' profits. The focal point of economic sustainability is to foster economic independence.

Each of these dimensions is as important as the other. The three bottom lines are seen as the integrative sustainability triangle whose implementation could avoid conflict (Tullberg, 2012) and produce an enabling environment to enhance business operation and continuous existence. In as much as CSR involves giving back to the society which is done mostly in form of developmental projects, it is also expected that these projects are able to meet the present as well as future need, hence, sustainability concerns. The pursuit of sustainable development will help address the proximate and trigger causes of the conflict (Idemudia and Ite, 2006a). Therefore, due consideration of these aspects to CSR by the multinational oil companies could reduce the negative impact of oil exploitation in the NDR.

\section{Methodology of Study}

The paper is a theoretical interdisciplinary study, which is drawn from a review of literature and deductive arguments on CSR and sustainability.

\section{The Niger Delta Crisis}

The Niger Delta region plays a significant role in the Nigerian economy because it is the main source of Nigeria's foreign exchange earnings. Ninety percent of the country's foreign exchange earnings are from this region. The level of instability in the region seems to have adverse effect in the plans to expand crude oil production. Projected annual revenues to the Nigerian government were expected to decline due to the Niger Delta crisis (International Crisis Group, 2006; UNDP, 2006). The Niger Delta conflict has persisted since 1990. There are three dimensions to the crisis; between the host communities and multinational oil companies, between the host communities and the government and between one host community and another. It is evident that if the communities are not in conflict with the multinational oil companies over land rights or compensation for environmental damage, they are in dispute with the government over access to oil wealth and resource control, or they are in conflict with one another over claim to ownership of area where oil facilities and accompanying benefits are situated (Idemudia and Ite, 2006b)

Ako (2012) posits that escalated violence over the years is due to economic, social and environmental deprivations. According to him, the oil companies are seen to have direct link with the federal government. The multinationals are criticized for adopting operating standards below those they adhere to in developed countries (Ako, 2012). Similarly, George et al (2012) opine that multinational oil companies operating in the NDR declare billions of dollars as profit yearly, while the communities are left without food, water and shelter due to the constant oil spillage which polluted their rivers and their farmlands and their youths are left unemployed which has resulted in youth restiveness in the NDR. These frustrations, hunger and anger led to the youths taking up arms, kidnapping the expatriate oil workers as well as destroying crude oil pipelines. The multinational oil companies operating in the Niger Delta especially are not taking the issue of CSR as seriously as it should have been. In the same vein Idemudia (2009) identifies poverty as a result of oil exploration because traditional sources of livelihood such as fishing and farming have been on the decline over the years and there has been little or no investment on alternative sources of livelihood to stimulate local economy. This has caused the host communities to be at logger-heads with the oil companies.

The political dimension of the crisis is that which concerns the communities and the government as regards resource control. Orogun (2010) argues that the Nigerian government derives its overwhelming revenue from the export of crude oil in the world market, yet indigenes of the oil rich region maintain that they have been marginalized, economically and politically and subjected to neglect, plagued by environmental degradation and brutal military occupation of their homeland as a result of perceived collusion and complicity between the Nigerian Government and the multinational oil corporations. The principle of allocation of revenue to the states where oil is produced has undergone several revision from 50 per cent to 20 per cent, 0 per cent, 2 per cent, 1.5 per cent and 13 per cent in 1975,1979, 1982, 1984, 1992 and 2001 respectively. This has also contributed to the feeling of deprivation of the people of the NDR (Idemudia and Ite, 2006a). Similarly, Afinotan and Ojakorotu (2009) attribute the ND crisis to struggle for self-determination, political dimension and the genuine struggle for the actualization of truly developed Niger Delta, free from poverty, degradation, unemployment, environmental pollution, economic and socio-political alienation, disease and squalor. The government is part of their problem and contributor to the crisis.

The conflicts between the host communities can be attributed to environmental factors. Afinotan and Ojakorotu (2009) estimated that in 40 years of oil exploration and production in Nigeria, over 60,000 spills have been recorded and over 2,000,000 barrels were discharged into the region eco-system from oil spillages alone between 1976 and 1996. In 1997 and 1998 over 106,000 spillages was recorded. As a result of the spillage some community members 
have encroached into other communities' land for search of livelihood. Gas flaring is also associated with atmospheric and thermal pollution and the depletion of vegetation and wild life (Afinotan and Ojakorotu, 2009). These environmental related issues have contributed to escalating the conflicts between the communities. The issue is the extent to which CSR implementation by multinational oil companies have impacted on the communities and how this has contributed positively or negatively to restiveness of youth other than economic development and how the security challenges has affected the oil producing companies. Since the Nigerian economy depends on petroleum extraction, it is important that any impediment should be tackled to avoid economic crisis.

\section{Implementation of CSR in the Niger Delta Region}

According to Ite (2004) lack of national macro-economic planning and management, backed by equitable resource allocation, and an enabling environment, have significant implications for the overall performances of CSR initiatives by multinational corporations in developing countries. George et al (2012) argue that the multinational oil companies operating in the Niger Delta especially are not taking the issue of CSR as seriously as it should have been. They also argue that the MOC especially in Nigeria are operating the concept of corporate philanthropy instead of CSR and this invariably makes them to become corporate social irresponsible organizations because oil spillage is still taking place and causing damage to the environment. Idemudia (2009)'s findings indicate that poverty can be reduced by creating new sources of livelihood through social investments and ensuring that existing sources of livelihoods are not destroyed or lost due to MOC operations. There is need for investment in social infrastructure to improve living standards in the Niger Delta region. Afinotan and Ojakorotu (2009) opine that emphasis should be laid on environmental sustainability issues. Similarly, Idemudia and Ite (2006a) are of the view that a focus on human development on the basis of economic, social and environmental sustainability is imperative for enduring peace to return to the Niger Delta region.

Ako, Lawrence and Okonmah (2009) suggest that MOC should take serious cognizance of contemporary trends in CSR within stakeholders' perspective and embrace them to promote a viable operating environment for their business activities. Idemudia and Ite (2006b) argue that the Niger Delta crisis can only be resolved through collective responsibility, Nigerian government meeting its social responsibility, the oil multinationals addressing their corporate social responsibilities as well as reciprocal responsibility on the part of the host communities. The pursuit of sustainable development will help address the proximate and trigger causes of the conflict. Eweje, (2007) concludes that no matter how laudable the CSR initiatives are, if the host communities do not feel that the project will create a sustainable economic, social and environmental development, the conflict and unrest in the Niger Delta will continue. These therefore call for an evaluation of the CSR policies of the MOC and the modification of their approach to CSR implementation. There is need to have collaborative participation of all stakeholders in both the need assessment and implementation of CSR initiatives of the MOCs

\section{Community Participation}

The host communities play a vital role in the successful operation of the oil MNCs by providing a peaceful working environment. Being a major stakeholder to the MNCs it is expected that their interest should be adequately accommodated. As mentioned by Eweje (2007), the host communities expect more from the oil companies in the provision of social development projects that provide hope for stable and prosperous future. The long-term effect of oil exploration activities as well as the CSR programmes and activities are borne by the host community hence the need for their involvement. Ako (2012) is of the view that host communities should be integrated into the planning and delivery process of CSR programmes. Similarly Orogun (2010) suggest that there should be a robust scholarly analytical framework of the role of indigenes of the oil producing communities in the political and economic determination of where and how the revenue generated from crude oil should be appropriated. This may not completely be acceptable by the MNCs because their CSR may be dependent on the company's policies and programmes, but it may be of no use investing in providing social infrastructure that is not the community's priority. The stakeholders' perspective will promote a viable operating environment for business activities (Ako et al., 2009).

\section{Conclusion}

There is an increased pressure for businesses to engage in CSR most of which are driven by compliance to regulatory authorities. In the Niger Delta region, there has been series of agitations and sometimes violent acts to protest what is perceived as suppression and denial of their rights to development. The oil companies have also not been spared the brunt of these agitations. In response to persistent, often violent demands to plough their huge profits back into the area, they have had to step up their community development and social responsibilities over the years. To actually ascertain the extent of involvement of oil companies, the issue of CSR has to be given due consideration. CSR has a powerful potential to make positive contributions to addressing the needs of disadvantaged communities especially 
in developing countries. On the other hand, there are ways in which CSR could, whether by mistake or design, damage the same communities, politically, social and economically. From the literature so far reviewed it is deduced that effective CSR programmes and activities should consider social, economic and environmental sustainability. The crisis in the NDR is attributed to factors ranging from environmental, political, economic and social factors which are believed can be resolved through collaborative efforts of the host communities, government and the MOC through enduring CSR initiatives. In the same vein, community participation in planning and implementation of CSR programmes will enhance its success and contribute to maintaining peaceful coexistence between the MOCs and the host communities.

\section{References}

Afinotan, L., \& Ojakorotu, V. (2009). The Niger Delta crisis: Issues, challenges and prospects. African Journal of Political Science and International Relations, 3(5), 191-198. http://dx.doi.org/10.5897/AJPSIR

Ako, R. (2012). Re-defining corporate social responsibility (CSR) in Nigeria's post-amnesty oil industry. African Journal of Economic and Management Studies, 3(1), 9-22. http://dx.doi.org/10.1108/20400701211197258

Ako, R., Lawrence O., \& Okonmah, P. (2009). Forging peaceful relationships between oil-companies and host-communities in Nigeria's Delta region. Journal of Enterprising Communities, 3(2), 205-216. http://dx.doi.org/10.1108/17506200910960888

Bowen, H. R. (1953). Social responsibility of the businessman. New York: Harper and Row.

Carroll, A. B. (1994). Social issues in management research: Experts' views, analysis and commentary. Business and Society, 33(1), 5-29. http://dx.doi.org/10.1177/000765039403300102

Carroll, A. B. (1999). Corporate social responsibility. Business and Society, 38(3), 268-295. doi:10.1177/000765039903800303

Dacin, P. A., \& Brown, T. J. (2006). Corporate branding, identity, and customer response. Journal of the Academy of Marketing Science, 34(2), 95-98.

Ejumudo, K., Edo, Z., Avweromre, L., \& Sagay, J. (2012). Environmental issues and corporate social responsibility(CSR) in Nigeria Niger Delta region: The need for a pragmatic approach. Journal of Social Science and Public Policy, 4, 1-21.

Elkington, J. (1998). Partnerships from cannibals with forks: The triple bottom line of 21st-century Business. Environmental Quality Management, 8(1), 37-51. http://dx.doi.org/10.1002/tqem.3310080106

Epstein, E. M. (2007). The good company: Rhetoric or reality? Corporate social responsibility and business ethics redux. American Business Law Journal, 44(2), 207-222. http://dx.doi.org/10.1111/j.1744-1714.2007.00035.x

Eweje, G. (2007). Multinational oil companies' CSR initiatives in Nigeria. Managerial Law, 49(5/6), 218-235. http://dx.doi.org/10.1108/03090550710841340

Friedman, M. (1970). The social responsibility of business is to increase its profits. New York Times, 13(32-33), 122-126.

Garriga, E., \& Melé, D. (2004). Corporate social responsibility theories: Mapping the territory. Journal of Business Ethics, 53(1/2), 51-71.

George, O. J., Kuye, O. L., \& Onokala, U. C. (2012). Corporate social irresponsibility (CSI) a catalyst to the Niger Delta crisis: The case of Nigerian oil multinational companies versus the militants of Niger Delta Region of Nigeria. Journal of Management Research, 4(2), 187-205. http://dx.doi.org/10.5296/jmr.v4i2.1186

Griseri, P., \& Seppala, N. (2010). Business ethics and corporate social responsibility. London: Cengage Learning.

Group, I. C. (2006). The swamps of insurgency: Nigeria's Delta unrest.

Gössling, T., \& Vocht, C. (2007). Social role conceptions and CSR policy success. Journal of Business Ethics, 74(4), 363-372. http://dx.doi.org/10.1007/s10551-007-9512-3

Hopkins, M. (2003). The planetary bargain: Corporate social responsibility matters. Sterling, VA: Earthscan Publications.

Idemudia, U. (2009). Oil extraction and poverty reduction in the Niger Delta: A critical examination of partnership initiatives. Journal of Business Ethics, 90(1), 91-116. http://dx.doi.org/10.1007/s10551-008-9916-8 
Idemudia, U., \& Ite, U. E. (2006a). Corporate-community relations in Nigeria's oil industry: Challenges and imperatives. Corporate Social Responsibility \& Environmental Management, 13(4), 194-206. http://dx.doi.org/10.1002/csr.101

Idemudia, U., \& Ite, U. E. (2006b). Demystifying the Niger Delta conflict: Towards an integrated explanation. Review of African Political Economy, 33(109), 391-406. http://dx.doi.org/10.1080/03056240601000762.

International Crisis Group. (2006). Nigeria: Want in the midst of plenty, Africa Report No, $11319^{\text {th }}$ Jul 2006. Brussels.

Ite, U. E. (2004). Multinationals and corporate social responsibility in developing countries: A case study of Nigeria. Corporate Social Responsibility and Environmental Management, 11(1), 1-11. http://dx.doi.org/10.1002/csr.49

Lewis, S. (2003). Reputation and corporate responsibility. Journal of Communication Management, 7(4), 356-365. http://dx.doi.org/10.1108/13632540310807494

Newell, P. (2005). Citizenship, accountability and community: The limits of the CSR agenda. International Affairs, 81(3), 541-557. http://dx.doi.org/10.1111/j.1468-2346.2005.00469.x

Orogun, P. S. (2010). Resource control, revenue allocation and petroleum politics in Nigeria: The Niger Delta question. GeoJournal, 75(5), 459-507. http://dx.doi.org/10.1007/s10708-009-9916-8

Sana-ur-Rehman, S., \& Beise-Zee, R. (2011). Corporate social responsibility or cause-related marketing? The role of cause specificity of CSR. The Journal of Consumer Marketing, 28(1), 27-39. http://dx.doi.org/10.1108/07363761111101921

Torugsa, N. A., O'Donohue, W., \& Hecker, R. (2013). Proactive CSR: An empirical analysis of the role of its economic, social and environmental dimensions on the association between capabilities and performance. Journal of Business Ethics, 115(2), 383-402. http://dx.doi.org/10.1007/s10551-012-1405-4

Tullberg, J. (2012). Triple bottom line - a vaulting ambition? Business Ethics: A European Review, 21(3), 310-324. http://dx.doi.org/10.1111/j.1467-8608.2012.01656.x

Tuodolo, F. (2009). Corporate social responsibility: Between civil society and the oil industry in the developing world. An International E-journal for Critical Geographies, 8(3), 530-541.

Tuzzolino, F. \& Armandi, B. R. (1981). A need-hierarchy framework for assessing corporate social responsibility. Academy of Management Review 6(1), 21-28. http://dx.doi.org/10.5465/AMR.1981.4287982

UNDP. (2006). Niger Delta human development report. Abuja: UNDP.

Wagner, M. (2010). The role of corporate sustainability performance for economic performance: A firm-level analysis of moderation effects. Ecological Economics, 69(7), 1553-1560. http://dx.doi.org/10.1016/j.ecolecon.2010.02.017

Walley, N., \& Whitehead, B. (1994). It's not easy being green. Harvard Business Review, 72(3), 46-51.

WBCSD. (2004). WBCSD urges business to invest in sustainable livelihood activities. Business \& the Environment with ISO 14000 Updates, 15(10), 10-10.

WCED. (1987). Our common future. Oxford: Oxford University Press.

Wood, D. J. (1991). Corporate social performance revisited. Academy of Management Review, 16(4), 691-718. http://dx.doi.org/10.5465/AMR.1991.4279616 